\title{
Fangchinoline inhibits the proliferation of SPC-A-1 lung cancer cells by blocking cell cycle progression
}

\author{
XUE LUO $^{1 *}$, JIAN-MING PENG ${ }^{1,2^{*}}$, LAN-DI SU ${ }^{1}$, DONG-YAN WANG $^{1}$ and YOU-JIANG YU ${ }^{1}$ \\ ${ }^{1}$ Medical College of Yangzhou Polytechnic College, Yangzhou, Jiangsu 225009; ${ }^{2}$ Key Laboratory of Pain, \\ Basic Research and Clinical Therapy, Medical College of Soochow University, Suzhou, Jiangsu 215123, P.R. China
}

Received January 13, 2015; Accepted September 24, 2015

DOI: 10.3892/etm.2015.2915

\begin{abstract}
Fangchinoline (Fan) is a bioactive compound isolated from the Chinese herb Stephania tetrandra S. Moore (Fen Fang Ji). The aim of the present study was to investigate the effect of Fan on the proliferation of SPC-A-1 lung cancer cells, and to define the associated molecular mechanisms. Following treatment with Fan, Cell Counting Kit-8, phase contrast imaging and Giemsa staining assays were used to detect cell viability; flow cytometry was performed to analyze the cell cycle distribution; and reverse transcription-quantitative polymerase chain reaction and western blot assays were used to investigate changes in the expression levels of cell cycle-associated genes and proteins. In the present study, treatment with Fan markedly inhibited the proliferation of SPC-A-1 lung cancer cells and significantly increased the percentage of cells in the $G_{0} / G_{1}$ phase of the cell cycle in a dose-dependent manner $(\mathrm{P}<0.05$ for $2.5-5 \mu \mathrm{m} ; \mathrm{P}<0.01$ for $10 \mu \mathrm{m})$, whereas the percentage of cells in the $S$ and $\mathrm{G}_{2} / \mathrm{M}$ phases were significantly reduced following treatment $(\mathrm{P}<0.05$ for $5 \mu \mathrm{m} ; \mathrm{P}<0.01$ for $10 \mu \mathrm{m})$. Mechanistically, Fan significantly reduced the mRNA expression levels of cyclin D1, cyclin-dependent kinase 4 (CDK4) and CDK6 ( $\mathrm{P}<0.05$ for $2.5-5 \mu \mathrm{m}$; $\mathrm{P}<0.01$ for $10 \mu \mathrm{m})$, which are key genes in the regulation of the $G_{0} / G_{1}$ phase of the cell cycle. Furthermore, treatment with Fan also decreased the expression of phosphorylated retinoblastoma $(\mathrm{Rb})$ and $\mathrm{E} 2 \mathrm{~F}$ transcription factor-1 (E2F-1) proteins ( $\mathrm{P}<0.05$ for $5 \mu \mathrm{m} ; \mathrm{P}<0.01$ for $10 \mu \mathrm{m})$. In summary, the present study demonstrated that Fan inhibited the proliferation of SPC-A-1 lung cancer cells and induced cell cycle arrest at the $\mathrm{G}_{0} / \mathrm{G}_{1}$ phase. These effects may be mediated by the downregulation of cellular CDK4, CDK6 and cyclin D1 levels, thus leading to hypophosphorylation of
\end{abstract}

Correspondence to: Mrs. You-Jiang Yu, Medical College of Yangzhou Polytechnic College, Building 4, 458 Wenchangzhong Road, Yangzhou, Jiangsu 225009, P.R. China

E-mail: shmily_peng@163.com

*Contributed equally

Key words: fangchinoline, lung cancer, cell cycle, retinoblastoma, cyclin D1
$\mathrm{Rb}$ and subsequent suppression of E2F-1 activity. Therefore, the present results suggest that Fan may be a potential drug candidate for the prevention of lung cancer.

\section{Introduction}

Non-small cell lung cancer (NSCLC) is among the most malignant types of tumor, with the highest incidence and mortality rates of any cancer variety worldwide. It has been reported that there were 239,320 new cases of lung cancer and 161,250 cases of mortality from lung cancer in the USA in 2010 (1). Although surgical excision, chemotherapy, radiation and targeted therapy have been applied to the treatment of lung cancer, the five-year survival rate remains at $\sim 15.6 \%$; thus, improved therapies for the treatment of NSCLC are urgently required $(1,2)$. Traditional Chinese herbs are considered to be a good source for the identification of novel anti-cancer agents (3).

Fangchinoline (Fan) is a bioactive compound isolated from the Stephania tetrandra S. Moore (Fen Fang Ji) Chinese herb. Various studies have demonstrated that Fan possesses a wide range of biological activities, including: Blood pressure lowering activity (4), histamine release inhibition (4), aortic vascular smooth muscle cell proliferation suppression (5), anti-oxidative stress (6) and antihypertensive activity (7). Furthermore, the anti-cancer activity of Fan has been indicated in various tumor cell models, including in cancer of the prostate $(8)$, breast $(9,10)$ and liver $(11)$, as well as leukemia (12). The molecular mechanisms of its anti-cancer activity include the induction of apoptosis, autophagy and cell cycle arrest; however, there is little information regarding the effect of Fan on NSCLC cells. In the present study, the antitumor effects of Fan and the associated molecular mechanisms were explored in NSCLC cells. Treatment with Fan stimulated cell cycle arrest at the $G_{0} / G_{1}$ phase in SPC-A-1 NSCLC cells via downregulation of cyclin-dependent kinase 4 (CDK4), CDK6 and cyclin D1, which subsequently repressed the expression of phosphorylated retinoblastoma protein (pRB) and E2F transcription factor-1 (E2F-1) . Therefore, the results of the present study suggest that Fan may potentially be useful in the prevention and treatment of NSCLC.

\section{Materials and methods}

Cell culture and agents. Human SPC-A-1 lung cancer cells (Cell Bank of the Chinese Academy of Sciences, Shanghai, 
China) were cultured in Dulbecco's modified Eagle medium (Invitrogen; Thermo Fisher Scientific, Inc., Waltham, MA, USA) supplemented with $10 \%$ heat-inactivated fetal bovine serum (Invitrogen; Thermo Fisher Scientific, Inc.) and $1 \%$ penicillin-streptomycin (Sangon Biotech Co., Ltd., Shanghai, China). Cells were maintained in a humidified atmosphere of $5 \% \mathrm{CO}_{2}$ at $37^{\circ} \mathrm{C}$. Fan (purity, $>98.0 \%$; Nature Standard Ltd., Shanghai, China) was prepared as a $50 \mathrm{mM}$ stock solution in dimethyl sulfoxide (DMSO), prior to supplementation into the medium at various concentrations, for 48 or $72 \mathrm{~h}$.

Cell Counting Kit-8 (CCK-8) assay. Cells were grown in 96-well culture plates and treated with various dosages of Fan $(1.25,2.5,5,10,20$ and $40 \mu \mathrm{M})$, as required, prior to incubation with $10 \mu \mathrm{l} \mathrm{CCK}-8$ for $2 \mathrm{~h}$. Following this, a Model 550 microplate reader (Bio-Rad Laboratories, Inc., Hercules, CA, USA) was used to measure the optical density (OD) of the samples at a wavelength of $450 \mathrm{~nm}$. The cell inhibitory rate (IR) was calculated, as follows: $\mathrm{IR}=\left[1-\left(\mathrm{OD}_{\text {experiment }}-\mathrm{OD}_{\text {blank }}\right) /\left(\mathrm{OD}_{\text {control }}-\mathrm{OD}_{\text {blank }}\right)\right] \mathrm{x} 100 \%$.

Cell imaging. Following treatment with Fan, phase contrast imaging and Giemsa staining assays were used to analyze the proliferation of SPC-A-1 lung cancer cells. SPC-A-1 cells were treated with various concentrations of Fan $(0,2.5$, 5 and $10 \mu \mathrm{M})$ and, after $48 \mathrm{~h}$, the cells were visualized under an inverted microscope (CKX41; Olympus, Tokyo, Japan) prior to staining with a Giemsa assay (Nanjing Jiancheng Bioengineering Institute, Nanjing, China), according to the manufacturer's instructions. In brief, the cells were fixed with the included solution I for $1 \mathrm{~min}$ and then solution II was added to stain the cells for another $5 \mathrm{~min}$. Subsequently, the solution was removed and the images of cells were obtained using the Olympus CKX41 microscope.

Flow cytometry analysis. SPC-A-1 cells were cultivated in a 6-well plate for $24 \mathrm{~h}$, prior to treatment with Fan $(0,2.5,5$ or $10 \mu \mathrm{M}$ ) or equal volumes of DMSO. Following $48 \mathrm{~h}$ incubation, the cells were collected, fixed in $70 \%$ ice-cold ethanol (Sangon Biotech Co., Ltd.) and maintained at $4^{\circ} \mathrm{C}$ overnight. Cells were then washed in phosphate-buffered saline and the resultant pellet was re-suspended in $200 \mu \mathrm{g} / \mathrm{ml}$ RNase (Sangon Biotech, Co. Ltd.) for $1 \mathrm{~h}$ at $37^{\circ} \mathrm{C}$. Cells were subsequently stained with $50 \mu \mathrm{g} / \mathrm{ml}$ propidium iodide, and analyzed using a flow cytometer (FACSCalibur; Beckman Coulter, Inc., Fullerton, CA, USA).

Reverse transcription-quantitative polymerase chain reaction $(R T-q P C R)$ assay. SPC-A-1 cells were treated with various concentrations of Fan for $48 \mathrm{~h}$ and the mRNA expression levels of genes that regulate the cell cycle were examined. Cells were collected and total RNA was extracted using TRIzol ${ }^{\circledR}$ reagent (Invitrogen; Thermo Fisher Scientific, Inc.). cDNA synthesis was performed using a RevertAid ${ }^{\mathrm{TM}}$ First Strand cDNA Synthesis kit (Thermo Fisher Scientific, Inc.) with $3 \mu \mathrm{g}$ total RNA, random hexamers (Fermentas; Thermo Fisher Scientific, Inc.) and specific oligonucleotide primers to detect the expression levels of cyclin D1, CDK4 and CDK6 mRNA. The sequences of the primer pairs were as follows: Cyclin D1, forward 5'-ATGCTGGAGGTCTGCGAGGA-3'
A

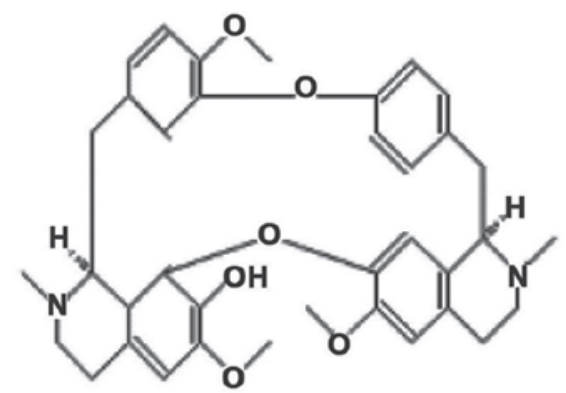

B

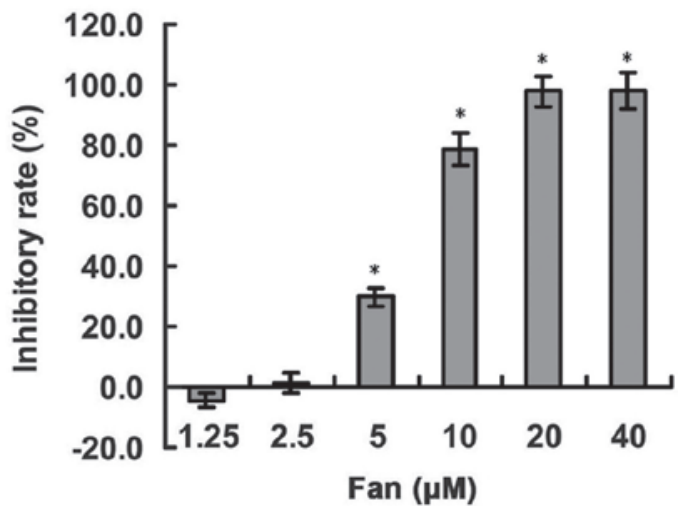

Figure 1. Growth inhibition effect of SPC-A-1 cells induced by Fan (A) Chemical structure of Fan. (B) SPC-A-1 cells were treated with the indicated concentrations of Fan or an equal volume of the dimethylsulfonide drug vehicle for $72 \mathrm{~h}$. Viable cells were evaluated by Cell Counting Kit- 8 assay and the inhibitory rate was calculated. Error bars indicate the mean \pm standard deviation $(n=3) .{ }^{*} \mathrm{P}<0.01$. Fan, fangchinoline.

and reverse 5'-TTCGATCTGCTCCTGGCAGG-3'; CDK4, forward 5'-TGGCTTTACTGAGGCGACTG-3' and reverse 5'-ACGGGTGTAGTGCCATCTG-3'; CDK6, forward 5'-GGA GTGCCCACTGAAACCAT-3' and reverse 5'-GTGAGACAG GGCACTGTAGG-3'; and glyceraldehyde 3-phosphate dehydrogenase (GAPDH), forward 5'-GAGAAGGCTGGGGCT CATTT-3' and reverse 5'-GTCAGGTCCACCACTGACAC-3'. GAPDH was used as an internal control. PCR was performed at a final reaction volume of $25 \mu \mathrm{l}$, containing $1 \mu \mathrm{l} \mathrm{cDNA}$, $1.5 \mathrm{mM} \mathrm{MgCl}, 1 \mathrm{U}$ Taq DNA polymerase, $0.2 \mathrm{mM}$ dNTP and $20 \mathrm{pM}$ of each gene-specific oligonucleotide primer. The PCR reaction conditions were as follows: Denaturation at $94^{\circ} \mathrm{C}$ for $30 \mathrm{sec}$, annealing at $52-56^{\circ} \mathrm{C}$ for $30 \mathrm{sec}$, and extension at $72^{\circ} \mathrm{C}$ for $45 \mathrm{sec}$. The amplified products were run on $1.5 \%$ agarose gel and documented using a Gel Doc XR+ system (Bio-Rad Laboratories, Inc.). The densitometric analysis of the RT-qPCR results was performed using Quantity One software, version 4.6.0 (Bio-Rad Laboratories, Inc.) using GAPDH for normalization.

Western blot analysis. SPC-A-1 cells were cultivated in 6-well plates for $24 \mathrm{~h}$, prior to treatment with Fan $(0,2.5$, 5 and $10 \mu \mathrm{M}$ ) or DMSO (0.02\%) for $48 \mathrm{~h}$. Protein expression was detected using $10 \%$ SDS-PAGE at $250 \mathrm{~V}$ for $90 \mathrm{~min}$. Subsequently, 20-30 $\mu \mathrm{g}$ total protein was transferred to polyvinylidene difluoride membranes and the membranes were blocked for 60 min with freshly prepared 5\% non-fat milk in Tris-buffered saline and Tween-20 (TBST). Following this, the membranes were incubated with rabbit monoclonal pRb $(1: 1,500 ; \# 8180)$, polyclonal E2F-1 (1:2,000; \#3742) 

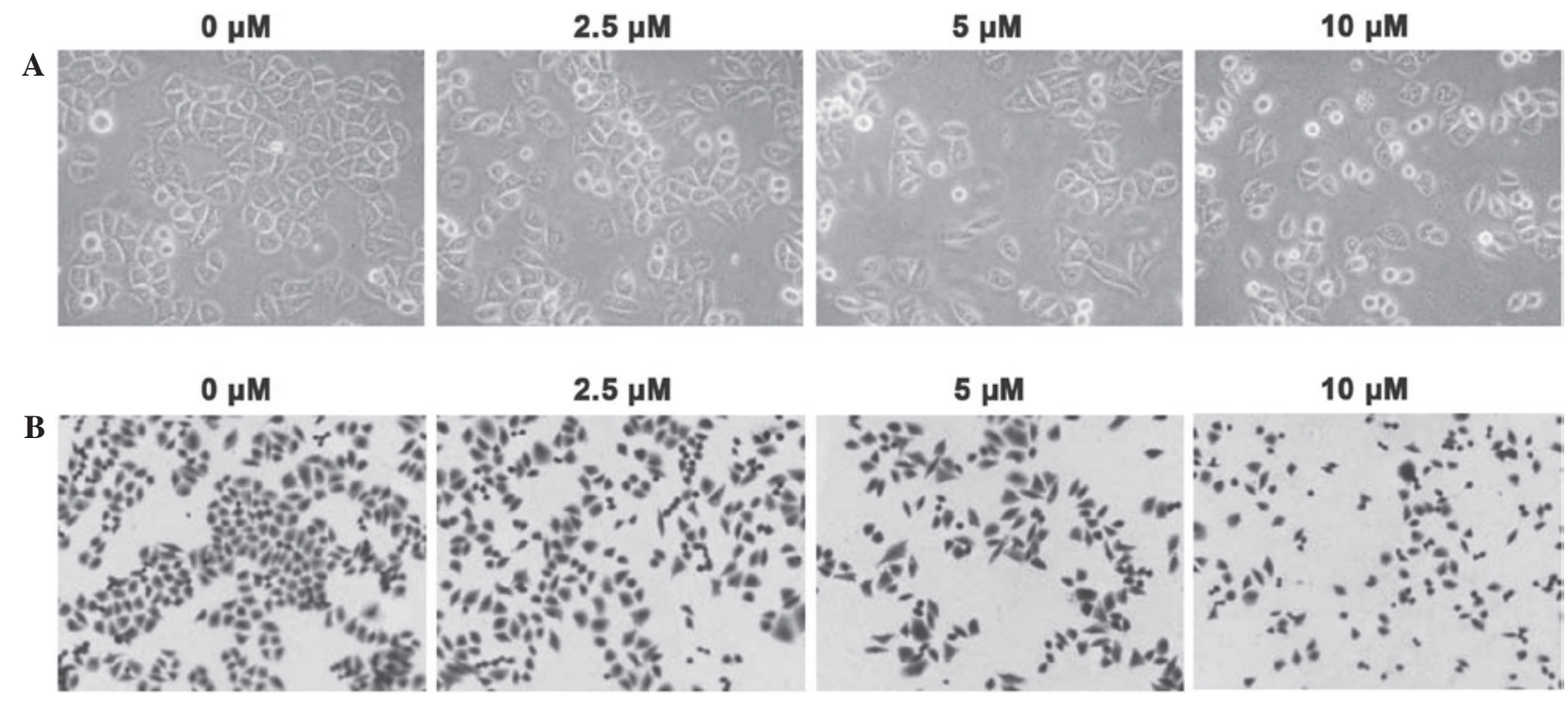

Figure 2. Proliferation of Fangchinoline (Fan)-inhibited SPC-A-1 cells (magnification, x200). (A) SPC-A-1 cells were treated with the indicated dosages of Fan for $48 \mathrm{~h}$ and visualized under a phase contrast microscope. (B) SPC-A-1 cells were incubated with Fan and stained with Giemsa staining, prior to visualization under a microscope.

A
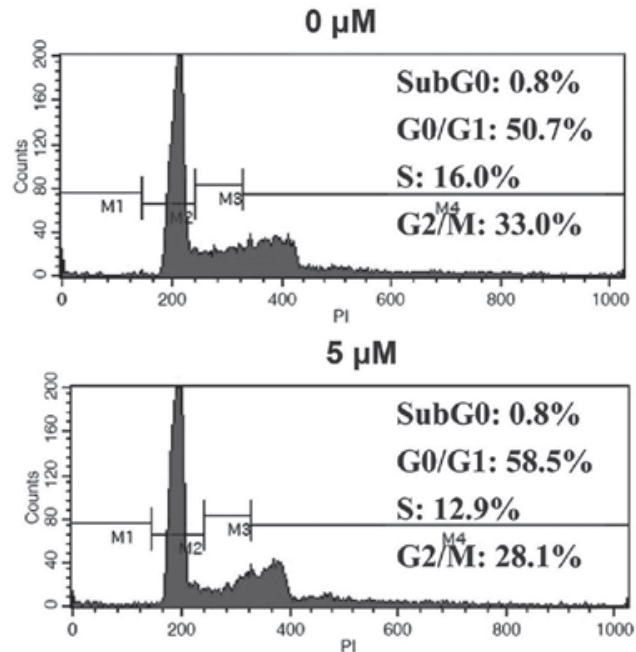
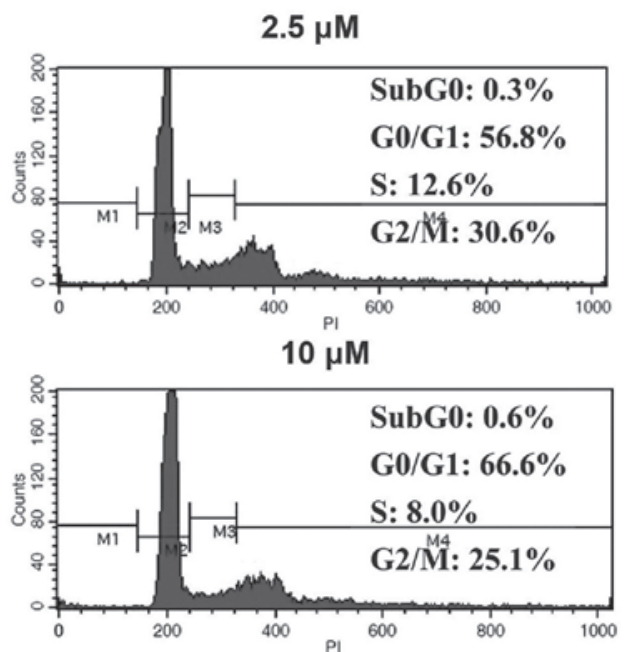

B

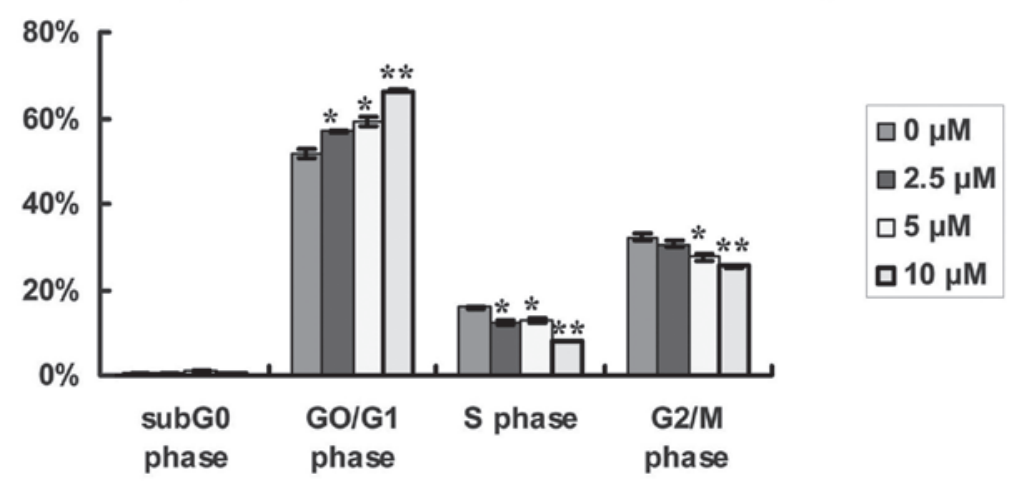

Figure 3. Fangchinoline (Fan)-induced SPC-A-1 cell cycle arrest. (A) SPC-A-1 cells were treated with the indicated concentrations of Fan for 48 h. Cell numbers

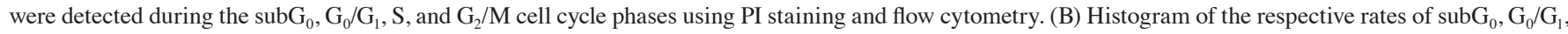
$\mathrm{S}$ and $\mathrm{G}_{2} / \mathrm{M}$ phase SPC-A-1 cell proliferation, determined via fluorescence-activated cell sorting analysis $(\mathrm{n}=3)$. ${ }^{*} \mathrm{P}<0.05$; ${ }^{* *} \mathrm{P}<0.01$ vs. control. $\mathrm{PI}$, propidium iodide.

and GAPDH (1:4,000; \#5174; Cell Signaling Technology, Inc., Danvers, MA, USA) primary antibodies, washed three times with TBST, and incubated with goat anti-mouse or goat anti-rabbit IgG-horseradish peroxidase-conjugated antibodies
(1:4,000; \#32260; Invitrogen; Thermo Fisher Scientific, Inc.) for $1 \mathrm{~h}$. Protein bands were revealed using a ECL Plus Western Blotting Detection System kit (GE Healthcare Life Sciences, Roosendaal, The Netherlands), with GAPDH used 

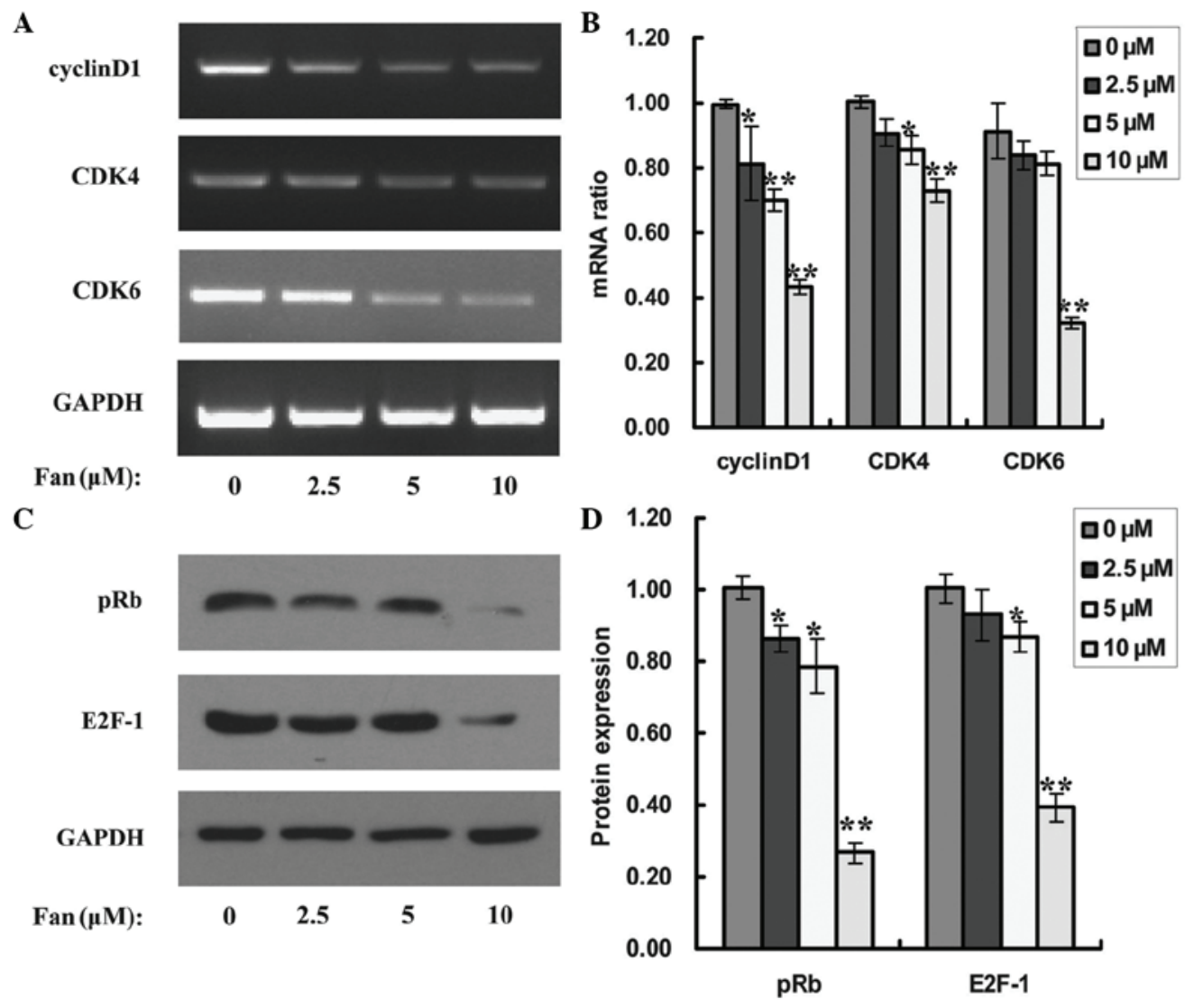

Figure 4. Expression levels of cell cycle-related genes and proteins affected by Fan in SPC-A-1 cells. (A) SPC-A-1 cells were treated with the indicated concentrations of Fan for $48 \mathrm{~h}$ and the mRNA expression levels of cyclin D1, CDK4, and CDK6 were detected using a reverse transcription-quantitative polymerase chain reaction. (B) The ratios of cyclin D1, CDK4 and CDK6 mRNA expression levels were calculated. (C) SPC-A-1 cells were treated by the indicated concentrations of Fan for $48 \mathrm{~h}$ and the expression levels of $\mathrm{pRb}$ and E2F-1 proteins were detected via western blot analysis. (D) The ratio of pRb and E2F-1 proteins was calculated. Error bars denote the mean \pm standard deviation $(n=3) .{ }^{*} \mathrm{P}<0.05 ;{ }^{* *} \mathrm{P}<0.01$ vs. control. CDK4, cyclin-dependent kinase; GAPDH, glyceraldehyde 3-phosphate dehydrogenase; Fan, fangchinoline; pRb, phosphorylated retinoblastoma protein; E2F-1, E2F transcription factor-1.

as a loading control. Densitometric analysis of the western blot was performed using Quantity One software, version 4.6.0 (Bio-Rad, Laboratories, Inc., USA), with GAPDH used for normalization.

Statistical analysis. All cellular experiments were performed at least three times. Data are expressed as the mean \pm standard deviation. Statistical analyses were performed using SPSS 14.0 for Windows (SPSS, Inc., Chicago, IL, USA). Experimental and control groups were compared using the unpaired Student's $\mathrm{t}$-test and one-way analysis of variance. $\mathrm{P}<0.05$ was considered to indicate a statistically significant difference.

\section{Results}

Fan inhibits the proliferation of SPC-A-1 lung cancer cells. To assess the inhibitory effect of Fan (Fig. 1A) on the growth and survival of lung cancer cells, human SPC-A-1 lung cancer cells were treated with Fan at concentrations of 1.25, 2.5, 5, 10, 20 and $40 \mu \mathrm{M}$ for $72 \mathrm{~h}$, using a CCK-8 assay. As shown in Fig. 1B, the proliferative inhibitory effect of Fan was observed in a concentration-dependent manner, with statistical significance $(\mathrm{P}<0.01$ for $5-40 \mu \mathrm{m})$. The half-maximal inhibitory concentration value of Fan in SPC-A-1 cells at $72 \mathrm{~h}$ was $7.19 \mu \mathrm{M}$. Furthermore, phase contrast imaging and Giemsa staining assays were also performed to measure the inhibitory function of Fan treatment (Fig. 2A and B, respectively). Following treatment with $2.5,5$ or $10 \mu \mathrm{M}$ Fan for $48 \mathrm{~h}$, the total cell number and cell volume of the SPC-A-1 cells decreased in a dose-dependent manner, and morphological changes, such as membrane blebbing, were detected. Thus, Fan appears to inhibit the proliferation of SPC-A-1 lung cancer cells.

Fan induces cell cycle arrest of SPC-A-1 cells at the $G_{0} / G_{1}$ phase. To determine whether Fan-induced suppression of cell proliferation was associated with an alteration in cell cycle distribution, the dose-dependent effects of Fan on the cell cycle distribution of lung cancer cells were measured (Fig.3A and B). Following treatment with 2.5, 5 or $10 \mu \mathrm{M}$ Fan for $48 \mathrm{~h}$, the proportion of SPC-A-1 cells in the $\mathrm{G}_{0} / \mathrm{G}_{1}$ phase $(56.86 \pm 0.19, \mathrm{P}<0.05 ; 59.12 \pm 1.00, \mathrm{P}<0.05$; and $66.22 \pm 0.32 \%, \mathrm{P}<0.01$; respectively) significantly increased, compared with the control $(51.84 \pm 1.06 \%)$; whereas the percentage of cells in the $\mathrm{S}$ phase significantly decreased from $15.78 \pm 0.17 \%$ (control), to $12.42 \pm 0.52(\mathrm{P}<0.05)$, $12.83 \pm 0.65(\mathrm{P}<0.05)$ and $7.96 \pm 0.05 \%(\mathrm{P}<0.01)$, respectively. Furthermore, the proportion of SPC-A-1 cells in the $\mathrm{G}_{2} / \mathrm{M}$ phase decreased in a dose-dependent manner from $32.16 \pm 0.81 \%$ (control) to $30.67 \pm 0.70(\mathrm{P}<0.05), 27.52 \pm 0.60(\mathrm{P}<0.05)$ and $25.38 \pm 0.29 \%(\mathrm{P}<0.01)$, respectively. These results indicated 
that Fan-induced inhibition of SPC-A-1 cell proliferation is cell cycle-dependent, and may result in the enhanced accumulation of cells in the $\mathrm{G}_{0} / \mathrm{G} 1$ phase. A representative profile of the cell cycle distribution is outlined in Fig. 3.

Fan affects cell cycle-related gene and protein expression in SPC-A-1 cells. D-type cyclins, such as cyclin D1, and its partner kinases CDK4 and CDK6, are central mediators of the G1 phase transition (13). To examine whether the enhancement of $\mathrm{G}_{0} / \mathrm{G}_{1}$ phase arrest in Fan-treated SPC-A-1 cells was a result of the dysregulation of cell cycle-related genes, the mRNA expression levels of cyclin D1, CDK4 and CDK6 were analyzed. The administration of Fan repressed the expression of cyclin D1, CDK4 and CDK6 mRNAs (Fig. 4A). Fan concentrations of 2.5, 5 and $10 \mu \mathrm{M}$ significantly inhibited cyclin D1 levels by $19(\mathrm{P}<0.05), 30(\mathrm{P}<0.01)$ and $57 \%(\mathrm{P}<0.01)$, respectively, compared with no treatment (Fig. 4B); whereas CDK4 expression levels were inhibited by $9(\mathrm{P}>0.05), 14(\mathrm{P}<0.05)$ and $27 \%(\mathrm{P}<0.01)$, respectively (Fig. 4B), and CDK6 expression levels were inhibited by $16(\mathrm{P}>0.05), 19(\mathrm{P}>0.05)$ and $68 \%(\mathrm{P}<0.01)$, respectively (Fig. 4B).

The cyclin D1-CDK4/6 complexes formed during the G1 phase may phosphorylate $\mathrm{Rb}$ protein and activate a transcriptional factor, E2F-1 (14). Therefore, to determine whether Fan suppressed the expression of cyclin D1, CDK4 and CDK6 via inhibition of the $\mathrm{pRB} / \mathrm{E} 2 \mathrm{~F}-1$ signaling pathway, the expression levels of pRB and E2F-1 in Fan-treated SPC-A-1 cells were examined, using a western blot assay. As demonstrated in Fig. 4C, treatment with Fan significantly inhibited the expression of pRB protein, and at 2.5, 5 and $10 \mu \mathrm{M}$, the suppression rates were $14(\mathrm{P}<0.05), 21(\mathrm{P}<0.05)$ and $73 \%(\mathrm{P}<0.01)$, respectively (Fig. 4D). Furthermore, Fan also significantly repressed the expression of $\mathrm{E} 2 \mathrm{~F}-1$ protein, and the suppression rates were determined to be $7,13(\mathrm{P}<0.05)$ and $61 \%(\mathrm{P}<0.01)$ at 2.5, 5 and $10 \mu \mathrm{M}$, respectively (Fig. 4C and D).

\section{Discussion}

Previous studies have demonstrated that Fan is associated with various functions, including: Blood pressure lowering activity (4), the inhibition of histamine release (4), anti-oxidative stress (6) and anti-cancer activity (9-11). However, little is known about the effect of Fan on cell cycle arrest in cancerous cells. Various studies have shown that Fan induces cell cycle arrest at the $\mathrm{G}_{0} / \mathrm{G}_{1}$ phase in breast cancer and leukemia cells, by decreasing the expression levels of CDK4 and cyclin D1 $(8,10,12)$. The present study demonstrated that, in SPC-A-1 lung cancer cells, Fan stimulated cell cycle arrest at the $G_{0} / G_{1}$ phase by downregulating the cellular levels of CDK4, CDK6 and cyclin D1, leading to the hypophosphorylation of $\mathrm{Rb}$ and the subsequent suppression of E2F-1 activity.

Cell proliferation is dependent on the progression of the cell cycle, which is composed of the $G_{1}, S, G_{2}$ and $M$ phases. The transition from the G1 to $\mathrm{S}$ phase is critical, as it controls the subsequent progress of the cell cycle. In the present study, Fan inhibited the proliferation of SPC-A-1 lung cancer cells in a dose-dependent manner, with $\mathrm{G}_{0} / \mathrm{G}_{1}$ phase accumulation, and a decrease in $\mathrm{S}$ and $\mathrm{G}_{2} / \mathrm{M}$ phase, demonstrating that Fan may have suppressed SPC-A-1 cell cycle initiation and blocked DNA synthesis. The $\mathrm{G} 1$ to $\mathrm{S}$ phase transition is tightly regulated by the activation of CDKs, which act consecutively in G1 to initiate the $\mathrm{S}$ phase, and in the $\mathrm{G} 2$ phase to initiate mitosis $(15,16)$. Therefore, it is unsurprising that the G1 checkpoint is the most conspicuous target for various anti-cancer agents. D-type cyclins, cyclin E and CDK4/6, CDK inhibitors and pRB are the central players of G1 phase transition $(15,17)$. Upon mitogenic stimulation, D-type cyclins, such as cyclin D1, are induced, and subsequently bind to and activate CDK4 and CDK6. These cyclin D-dependent kinases then initiate the phosphorylation of $\mathrm{Rb}$, relieving the inhibition of E2F-1 and allowing for the expression of specific E2F-1 target genes (18). In the present study, Fan suppressed the expression of cyclin D1, CDK4 and CDK6, suggesting that Fan successfully blocked the cell cycle progression of SPC-A-1 lung cancer cells. Considering that previous studies have determined that the CDK4/6 complex phosphorylates Rb protein (18-20), it is logical that the administration of Fan may also have suppressed the phosphorylation of $\mathrm{Rb}$. As a tumor suppressor protein, $\mathrm{Rb}$ may inhibit cancer cell proliferation via cell cycle arrest, as it is the hyperphosphorylation of $\mathrm{Rb}$ that induces $\mathrm{Rb}$ to dissociate from E2F-1 and subsequently promotes the G1 to $S$ phase transition $(19,20)$. In the present study, Fan inhibited the phosphorylation of $\mathrm{Rb}$ protein and $\mathrm{E} 2 \mathrm{~F}-1$, which may have resulted from the Fan-induced inhibition of CDK4, CDK6 and cyclin D1.

In conclusion, the present study suggested that Fan promotes the cell cycle arrest of SPC-A-1 lung cancer cells at the $G_{0} / G_{1}$ phase by downregulating the cellular levels of CDK4, CDK6 and cyclin D1, leading to hypophosphorylation of $\mathrm{Rb}$ and subsequent suppression of the E2F-1 activity. Thus, the present results suggest that Fan may be a potential drug candidate for the prevention of lung cancer and have clinical applications in the future, and E2F-1 may be an effective target for consideration in anti-lung cancer drugs.

\section{Acknowledgements}

The work of the present study was supported by funding from the Jiangsu Province Health Department (grant no. J201410) and the Yangzhou Vocational College of Environment and Resources.

\section{References}

1. Siegel R, Ward E, Brawley O and Jemal A: Cancer statistics, 2011: The impact of eliminating socioeconomic and racial disparities on premature cancer deaths. CA Cancer J Clin 61: 212-236, 2011.

2. Mutlu H, Buyukcelik A, Aksahin A, Kibar M, Cihan YB, Kaya E, Seyrek E, Yavuz S, Erden A, Calikusu Z, Aslan T and Akca Z: Does sunlight exposure improve survival in patients with non-small cell lung cancer? Asian Pac J Cancer Prev 14: 6301-6304, 2013.

3. Li SG, Chen HY, Ou-Yang CS, Wang XX, Yang ZJ, Tong Y and Cho WC: The efficacy of Chinese herbal medicine as an adjunctive therapy for advanced non-small cell lung cancer: A systematic review and meta-analysis. Plos One 8: e57604-e57615, 2013.

4. Nakamura K, Tsuchiya S, Sugimoto Y, Sugimura Y and Yamada Y: Histamine release inhibition activity of bisbenzylisoquinoline alkaloids. Planta Med 58: 505-508, 1992.

5. Zhang YH, Fang LH and Ku BS: Fangchinoline inhibits rat aortic vascular smooth muscle cell proliferation and cell cycle progression through inhibition of ERK1/2 activation and c-fos expression. Biochem Pharmacol 66: 1853-1860, 2003.

6. Sekiya N, Hikiami H, Yokoyama K, Kouta K, Sakakibara I, Shimada Y and Terasawa K: Inhibitory effects of Stephania tetrandra S. Moore on free radical-induced lysis of rat red blood cells. Biol Pharm Bull 28: 667-670, 2005. 
7. Kim HS, Zhang YH, Oh KW and Ahn HY: Vasodilating and hypotensive effects of fangchinoline and tetrandrine on the rat aorta and the stroke-prone spontaneously hypertensive rat. J Ethnopharmacol 58: 117-123, 1997.

8. Wang CD, Huang JG, Gao X, Li Y, Zhou SY, Yan X, Zou A, Chang JL, Wang YS, Yang GX and He GY: Fangchinoline induced G1/S arrest by modulating expression of p27, PCNA, and cyclin D in human prostate carcinoma cancer PC3 cells and tumor xenograft. Biosci Biotechnol Biochem 74: 488-493, 2010.

9. Xing ZB, Yao L, Zhang GQ, Zhang XY, Zhang YX and Pang D: Fangchinoline inhibits breast adenocarcinoma proliferation by inducing apoptosis. Chem Pharm Bull (Tokyo) 59: 1476-1480, 2011.

10. Xing Z, Zhang $Y$, Zhang $X$, Yang $Y$, Ma Y and Pang D Fangchinoline induces G1 arrest in breast cancer cells through cell-cycle regulation. Phytother Res 27: 1790-1794, 2013.

11. Wang N, Pan W, Zhu M, Zhang M, Hao X, Liang G and Feng Y: Fangchinoline induces autophagic cell death via p53/sestrin2/AMPK signalling in human hepatocellular carcinoma cells. Br J Pharmacol 164 (2b): 731-742, 2011.

12. Wang Y, Chen J, Wang L, Huang Y, Leng Y and Wang G: Fangchinoline induces $\mathrm{G} 0 / \mathrm{G} 1$ arrest by modulating the expression of CDKN1A and CCND2 in K562 human chronic myelogenous leukemia cells. Exp Ther Med 5: 1105-1112, 2013.
13. Chiron D, Martin P, Di Liberto M, Huang X, Ely S, Lannutti BJ, Leonard JP, Mason CE and Chen-Kiang S: Induction of prolonged early G1 arrest by CDK4/CDK6 inhibition reprograms lymphoma cells for durable PI3Kdelta inhibition through PIK3IP1. Cell Cycle 12: 1892-1900, 2013.

14. Xu X, Zhang J, Han K, Zhang Z, Chen G, Zhang J, Mao X and Cao B: Natural pesticide dihydrorotenone arrests human plasma cancer cells at the G0/G1 phase of the cell cycle. J Biochem Mol Toxicol 28: 232-238, 2014.

15. Lim S and Kaldis P Cdks, cyclins and CKIs: Roles beyond cell cycle regulation. Development 140: 3079-3093, 2013.

16. Genovese C, Trani D, Caputi M and Claudio PP: Cell cycle control and beyond: Emerging roles for the retinoblastoma gene family. Oncogene 25: 5201-5209, 2006.

17. Xu P, Jiang EJ, Wen SY and Lu DD: Amentoflavone acts as a radioprotector for irradiated v79 cells by regulating reactive oxygen species (ROS), cell cycle and mitochondrial mass. Asian Pac J Cancer Prev 15: 7521-7526, 2014.

18. Wang YX, Cai H, Jiang G, Zhou TB and Wu H: Silibinin inhibits proliferation, induces apoptosis and causes cell cycle arrest in human gastric cancer MGC803 cells via STAT3 pathway inhibition. Asian Pac J Cancer Prev 15: 6791-6798, 2014.

19. Giacinti C and Giordano A: RB and cell cycle progression. Oncogene 25: 5220-5227, 2006.

20. Blain SW: Switching cyclin D-Cdk4 kinase activity on and off Cell Cycle 7: 892-898, 2008. 